\title{
Effects of Temperature and Duration of Preconditioning Cold Treatment on Sclerotial Germination of Claviceps purpurea
}

Sai Sree Uppala, Central Oregon Agricultural Research Center, Madras, OR 97741; B. M. Wu, Department of Plant Pathology, China Agricultural University, Beijing; and S. C. Alderman, United States Department of Agriculture-Agricultural Research Service National Forage Seed Production Research Center, Corvallis, OR, 97331

\begin{abstract}
Uppala, S., Wu, B. M., and Alderman, S. C. 2016. Effects of temperature and duration of preconditioning cold treatment on sclerotial germination of Claviceps purpurea. Plant Dis. 100:2080-2086.

Claviceps purpurea is an important ovary-infecting pathogen that replaces seed with sclerotia in Kentucky bluegrass grown for seed. Sclerotia overwinter in the soil and germinate in the spring to produce ascospores that infect grass seed ovaries. To better understand environmental conditions affecting ascospore production, the effects of preconditioning cold treatment and subsequent incubation temperature on germination of sclerotia were determined in growth chambers under controlled conditions. Preconditioning cold treatment was essential for germination only in treatments where the incubation temperature was high (at least higher than $20^{\circ} \mathrm{C}$ ). At lower incubation temperatures $\left(10\right.$ to $20^{\circ} \mathrm{C}$ ), preconditioning also played a role in improving sclerotial germination. Preconditioning at $4^{\circ} \mathrm{C}$ (in darkness) for 4 to 8 weeks followed by incubation at 10 and $20^{\circ} \mathrm{C}$

(cycle of $12 \mathrm{~h}$ each of darkness and light), or constant $15^{\circ} \mathrm{C}$ (cycle of $12 \mathrm{~h}$ each of darkness and light), was optimal for ergot germination. When sclerotia were preconditioned for 4 weeks or longer, number of incubation days required for initiation of germination was not affected by temperature in the range from 10 to $25^{\circ} \mathrm{C}$ (cycle of $12 \mathrm{~h}$ each of darkness and light), although the duration of germination (or the progress speed of germination) was still affected by temperature. A simple model was developed based on laboratory results and validated with historic spore trap data collected from various Kentucky bluegrass fields in Oregon (Willamette Valley, central Oregon, and Grande Ronde Valley). The prediction model could predict ascospore onset well and explained 55\% of variation in the data.
\end{abstract}

Kentucky bluegrass (Poa pratensis L.) is a medium-textured, dark-green, perennial amenity turf grass which is used in many temperate climate areas of the United States and around the world. In the Pacific Northwest, Kentucky bluegrass seed is an important commodity, contributing \$15 million revenue to Oregon (Oregon State University 2013) and $\$ 17$ million to Washington State (USDANASS 2013) in 2012. Primary production regions include the Grande Ronde Valley in northeastern Oregon, the Rathdrum Prairie in eastern Washington and northern Idaho, and central Oregon (Butler et al. 2001). Ergot, caused by Claviceps purpurea (Fr.) Tul., is one of the most serious diseases in Kentucky bluegrass grown for seed (Alderman et al. 1998; Butler et al. 2002), and it is an economically important disease in all the major production areas in the Pacific Northwest (Alderman 1991; Alderman et al. 1996; 1998; Schultz et al. 1993). The fungal pathogen overwinters in soil as sclerotia (ergot bodies) and produce stromata the next spring. A cold preconditioning period of at least several weeks at 0 to $10^{\circ} \mathrm{C}$ was reported to be required for germination of sclerotia (Mitchell and Cooke 1968). Ascospores produced from perithecia in the stromata are forcibly ejected into the air and serve as the primary inoculum source (Bove 1970). Ascospores infect ovaries of grass flowers by entering primarily through stigmas (Luttrell 1980) during the flowering period. The susceptibility of grass plants diminishes rapidly after pollination (Campbell and Tyner 1959; Cunfer et al. 1975; Darlington and Mathre 1976). A lesion develops at the base of the infected ovary, from which xylem and phloem sap flow into the floral cavity. This sap facilitates the further colonization of the ovary tissues by the fungus and formation of conidia. The sap-conidia mixture is exuded to the exterior of the floret to appear as droplets of honeydew 7 to 10 days after infection (Luttrell 1980; Mower and Hancock 1975a,b). The conidia in honeydew can be

Corresponding author: B. M. Wu; Email: bmwu@cau.edu.cn

Accepted for publication 9 May 2016.

http://dx.doi.org/10.1094/PDIS-02-16-0215-RE

(C) 2016 The American Phytopathological Society disseminated by mechanical transfer, water splashes, or insects to healthy flowers, and cause new infections if the flowers are still open (Butler et al. 2001). As the infection process continues, the floret is colonized and replaced completely with a purple-black sclerotium or ergot, which usually prominently protrudes from the affected floret (Shaw 1986).

C. purpurea attacks many grass species, including native wild grasses, cereal crops, and grasses important to seed production in Oregon such as tall fescue, ryegrass, and bentgrass (Alderman and Barker 2003; Alderman et al. 2004). The disease can cause direct seed yield reduction when sclerotia replace seed, difficulties in harvest caused by honeydew, lower market value due to contamination of seed by sclerotia of the pathogen, reduced seed vigor, and seed loss during additional seed cleanings to remove sclerotia (Chastain 1992; Schultz et al. 1993).

Even though significant progress has been made in understanding ergot during the past century, ergot management continues to be a challenge (Alderman 2006). Thus far, ergot management is based on reducing the primary inoculum source through deep plowing (Bretag and Merriman 1981), residue burning (Johnston et al. 1996), and spraying fungicide to inhibit ascospore production (Wood and Coley-Smith 1980). These management practices, aimed at reducing the source of primary inoculum, have proven to be ineffective or impractical, and recent ergot control efforts have focused on applying fungicides to protect plants during the flowering period (Hamm et al. 2007, 2008; Schultz et al. 1993). Spraying fungicides at the flowering stage can provide protection to flowers at the susceptible stage but efficacy varies with the timing of application (Hamm et al. 2007, 2008; Schultz et al. 1993; Walenta et al. 2009; Wu et al. 2010) Currently, one or more applications of fungicides, starting at anthesis, are adopted widely by grass growers in Oregon to lower ergot infections in grass seed production (Walenta et al. 2009).

The quantity of ascospores during the flowering period is known to affect the level of ergot infection (Alderman et al. 2010; Walenta et al. 2009). Ergot severity can vary from year to year (Alderman et al. 2010; Cagas and Machac 2002). Walenta et al. (2009) observed some years with low ergot incidence and attributed it to lack of coincidence between timing of ascospore release by the fungus and 
timing of grass seed anthesis, which is the only period of host susceptibility. Various factors (plant related and weather related) presumably affect ascospore onset and ergot infection. Alderman et al. (2010) monitored ascospores during anthesis and reported diurnal periodicity of ascospore release, with most ascospores trapped during late-evening through early-morning hours.

It was observed that more sprinkler irrigation and rainfall might contribute to severe ergot disease (Alderman 1993). Temperature is another important weather factor that is known to affect ergot in various crops (Gupta et al. 1983; McCrea 1931; Montes-García et al. 2009). In pearl millet, atmospheric temperature was reported to contribute $45 \%$ of total variation of the ergot infection index (Gupta et al. 1983). Mitchell and Cooke (1968) reported that sclerotia of $C$. purpurea from Phalaris arundinacea required several weeks of incubation or preconditioning at 0 to $10^{\circ} \mathrm{C}$ to activate germination. Under controlled temperatures, Alderman (1993) observed increased release of ascospores as temperature rose from 5 to $20^{\circ} \mathrm{C}$. However, the relationship between temperature and ascospore release in Kentucky bluegrass fields has not been well understood. Understanding the effect of different environmental conditions on ergot might explain the varying levels of ergot among years.

Fungicide sprays may be unnecessary if no or few ascospores are available during the susceptible period of grass flowers. To save unnecessary fungicide sprays, optimize timing of fungicide sprays to achieve better disease control, and allow some time for preparation and action of fungicide applications, accurate prediction of ascospore availability during the flowering period of Kentucky bluegrass is critical. Therefore, the objectives of this study were to (i) quantify germination of sclerotia (ergot bodies) at various incubation temperatures with and without preconditioning cold treatment in the laboratory under controlled conditions, (ii) develop a model to predict the onset of ascospore production based on the results from the laboratory study, and (iii) validate the model with ascospore trapping data from commercial Kentucky bluegrass fields in Oregon.

\section{Materials and Methods}

Laboratory studies. Sclerotia of $C$. purpurea from Kentucky bluegrass were used in all experiments. For experiments 1 and 5, sclerotia were collected in 2011 from infected plants in a research field at Central Oregon Agricultural Research Center, Madras, OR. For experiments 2, 3 , and 4, sclerotia were hand picked from infested seed lots provided by CHS Inc., Madras, OR. For each experiment, intact sclerotia were surface sterilized with $2 \%$ bleach for 2 min and rinsed three times with sterilized distilled water. Fifty sclerotia were placed on a polyurethane disc ( $7.5 \mathrm{~cm}$ in diameter, $2.5 \mathrm{~cm}$ thick, autoclaved at $121^{\circ} \mathrm{C}$ for $15 \mathrm{~min}$ ) in a Styrofoam cup $(6 \mathrm{~cm}$ in height, with diameters of 7 and $8.5 \mathrm{~cm}$ at the bottom and top, respectively). Cups were punched with four 2-mmdiameter holes at a 1-cm height from the bottom to facilitate drainage of excessive water. Two cups were included for each treatment. Cups were covered with lids from 100-mm petri dishes. Sclerotia were sprayed with water until saturation and subjected to preconditioning periods of 0 (C0), 2 (C2), 4 (C4), 6 (C6), and 8 (C8) weeks at $4^{\circ} \mathrm{C}$ (in darkness), and sterilized distilled water was sprayed once a week to maintain moisture. After the preconditioning period, cups with sclerotia were incubated at constant $4^{\circ} \mathrm{C}$ (in darkness); 15,20 , or $25^{\circ} \mathrm{C}$; or at 10 and $20^{\circ} \mathrm{C}$ (cycle of $12 \mathrm{~h}$ each of darkness and light, respectively; $10 / 20^{\circ} \mathrm{C}$ hereafter). The sclerotia were sprayed twice a week with sterilized distilled water using a hand sprayer. Germination of sclerotia was monitored and recorded twice a week after the first appearance of stromata. Any sclerotium with a discernible stroma was considered germinated. The treatments were arranged according to a split-plot design, with incubation temperature as the main-plot factor and preconditioning cold treatment period as the subplot factor. The whole experiment was conducted four times. However, 15 and $20^{\circ} \mathrm{C}$ treatment combinations were repeated one more time, thus making five experiment runs for these two incubation temperatures. Preliminary results from experiment 1 were previously published (Uppala et al. 2012).

Field studies. Volumetric spore traps (Burkard Manufacturing Co., Rickmansworth, England) were placed in two Kentucky bluegrass field sites in Willamette Valley (Aurora I and Aurora II) near Aurora, OR during 1989 and 1990; two Kentucky bluegrass field sites in Grande Ronde Valley (La Grande I and La Grande II) near La Grande, OR during 2008, 2009, and 2010; and two Kentucky bluegrass field sites in Central Oregon (Madras I and Madras II) near Madras, OR in 2011. Traps were placed within fields in mid-April to the end of June and removed before harvest. Tapes from spore traps were stained with analine blue and mounted on slides as previously described (Alderman 1993; Alderman et al. 2010). Ascospores of C. purpurea were observed under a microscope at $\times 100$ to $\times 400$ and daily counts were obtained by summing counts from 12:00 P.M. to 11:59 A.M. each day. Standard slides of $C$. purpurea ascospores and grass seed pollens were used for comparison during the identification process.

Fields were maintained under recommended management practices. Preliminary results from Madras I and Madras II fields were previously published (Uppala et al. 2011). Field locations and dates of ascospore trapping are provided in Table 1 . Daily mean air temperature data for all locations were compiled from the nearest available Agrimet weather stations. On the other hand, soil temperature at the 2-in. $(5.08 \mathrm{~cm})$ depth was not available for the two sites near Aurora in 1989 and 1990 and the two sites near Madras in 2011. Under these circumstances, a regression model developed using available data from the other sites was used to estimate soil temperature at the 2-in. depth based on observed air temperature data.

Data analysis. For each combination of incubation temperaturepreconditioning treatment, a logistic model of $g=a /[1+\exp (-b t+c)]$, where $g$ is percentage of sclerotia germinated; $t$ is days of incubation; and $a, b$, and $c$ are asymptote, progress rate, and initial threshold, respectively, was fitted to the pooled data from all replications and experiments using a nonlinear regression procedure in SAS 9.2 (SAS Institute Inc., Cary, NC). Nonlinear regression was also done on each combination of replication-temperature-preconditioning treatment. Parameters $a, b$, and $c$ estimated from the regression were then analyzed by using a mixed linear model (Proc Mixed in SAS) to test the effects of fixed factors, including incubation temperatures, length of preconditioning cold treatment, and their interactions, on the three parameters. Effects of replication and combination of replication and temperature were considered to be random effects in the regression. The estimated parameters were included in the analysis only when the nonlinear regression succeeded to converge and the model passed the $F$ test at a 0.01 significance level; otherwise, they were considered missing. Germination percentage at 60 days after the start of the experiment or days after incubation, minimum time required for the onset of germination (germination of first ergot body), and the duration of germination (time from initiation to stabilization of germination count) in each treatment were also analyzed by mixed linear model analysis.

Because the results of the laboratory study suggested that the incubation time (days) required for initial germination was not affected by

Table 1. Details of field locations and dates of seasonal ascospore trapping

\begin{tabular}{|c|c|c|c|}
\hline \multirow[b]{2}{*}{ Field name } & \multirow[b]{2}{*}{ Location } & \multicolumn{2}{|c|}{ Dates of spore trap } \\
\hline & & From & To \\
\hline \multicolumn{4}{|l|}{1989} \\
\hline Aurora I & O. M. Scott Research farm & 18 April & 19 June \\
\hline Aurora II & Pure seed testing research farm & 18 April & 19 June \\
\hline \multicolumn{4}{|l|}{1990} \\
\hline Aurora I & O. M. Scott Research farm & 11 April & 19 June \\
\hline Aurora II & Pure seed testing research farm & 11 April & 25 June \\
\hline \multicolumn{4}{|c|}{ 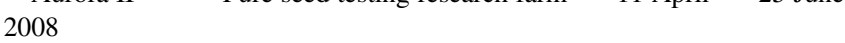 } \\
\hline La Grande I & LaGrande, OR & 13 May & 7 July \\
\hline La Grande II & LaGrande, OR & 13 May & 30 July \\
\hline \multicolumn{4}{|l|}{2009} \\
\hline La Grande I & LaGrande, OR & 13 May & 22 June \\
\hline La Grande II & LaGrande, OR & 13 May & 5 July \\
\hline \multicolumn{4}{|l|}{2010} \\
\hline La Grande I & LaGrande, OR & 21 April & 12 July \\
\hline La Grande II & LaGrande, OR & 21 April & 10 July \\
\hline \multicolumn{4}{|l|}{2011} \\
\hline Madras I & Grower's field in Madras, OR & 30 May & 4 July \\
\hline Madras II & COARC, Madras, OR & 30 May & 4 July \\
\hline
\end{tabular}


incubation temperature after sclerotia were cold treated for 4 weeks or longer, a model for predicting the initiation of ascospore release was constructed as follows. Starting from January 1, if daily mean temperature is higher than $4^{\circ} \mathrm{C}$ (or 4-day average higher than $0^{\circ} \mathrm{C}$ ), then the conditions are good for preconditioning. Once sclerotia have gone through 28 days of preconditioning, then they take about 25 days of incubation to produce ascospores if the temperature is between 7.5 and $25^{\circ} \mathrm{C}$. The incubation duration requirements can be met with short interruptions of low or high temperature totaling no more than 6 days (or, within the past 31 days, there were at least 25 days with a temperature between 7.5 and $25^{\circ} \mathrm{C}$ ). The observed and predicted dates for the onset of ascospore release were compared, and a linear model was fitted for the relationship between them.

\section{Results}

Laboratory studies. Regardless of the length of preconditioning cold treatment, no germination was observed for sclerotia incubated at $4^{\circ} \mathrm{C}$ even after more than 200 days of incubation in this study (data not shown). Without the preconditioning cold treatment, no germination was observed at $25^{\circ} \mathrm{C}$ but some (average $=11 \%$ ) sclerotia germinated at $25^{\circ} \mathrm{C}$ when they were subjected to preconditioning for 4 weeks or longer, with no significant difference among 4, 6, or 8 weeks of preconditioning (Fig. 1). For all other incubation temperatures tested in this study, the longer the cold treatment period, the shorter was the time required for initiation of ergot germination; the maximum germination rate reached $60 \%$ or higher within 60 days in most cases, varying with incubation temperature and length of preconditioning period (Fig. 1).

When each replication and treatment combination was regressed separately, most of these combinations could be fitted to the logistic model $g=a /[1+\exp (-b t+c)]$ (Fig. 1) with a high degree of confidence, with exceptions for combinations of $\mathrm{C} 0$ at $25^{\circ} \mathrm{C}$ and $\mathrm{C} 2$ at $25^{\circ} \mathrm{C}$, where no germination or a very small percentage of germination was recorded. Results from Proc Mixed Analysis on the estimated parameters of logistic curves revealed that the maximum percentage of sclerotia germinated (parameter $a$ of the logistic model) was significantly affected by incubation temperature and its

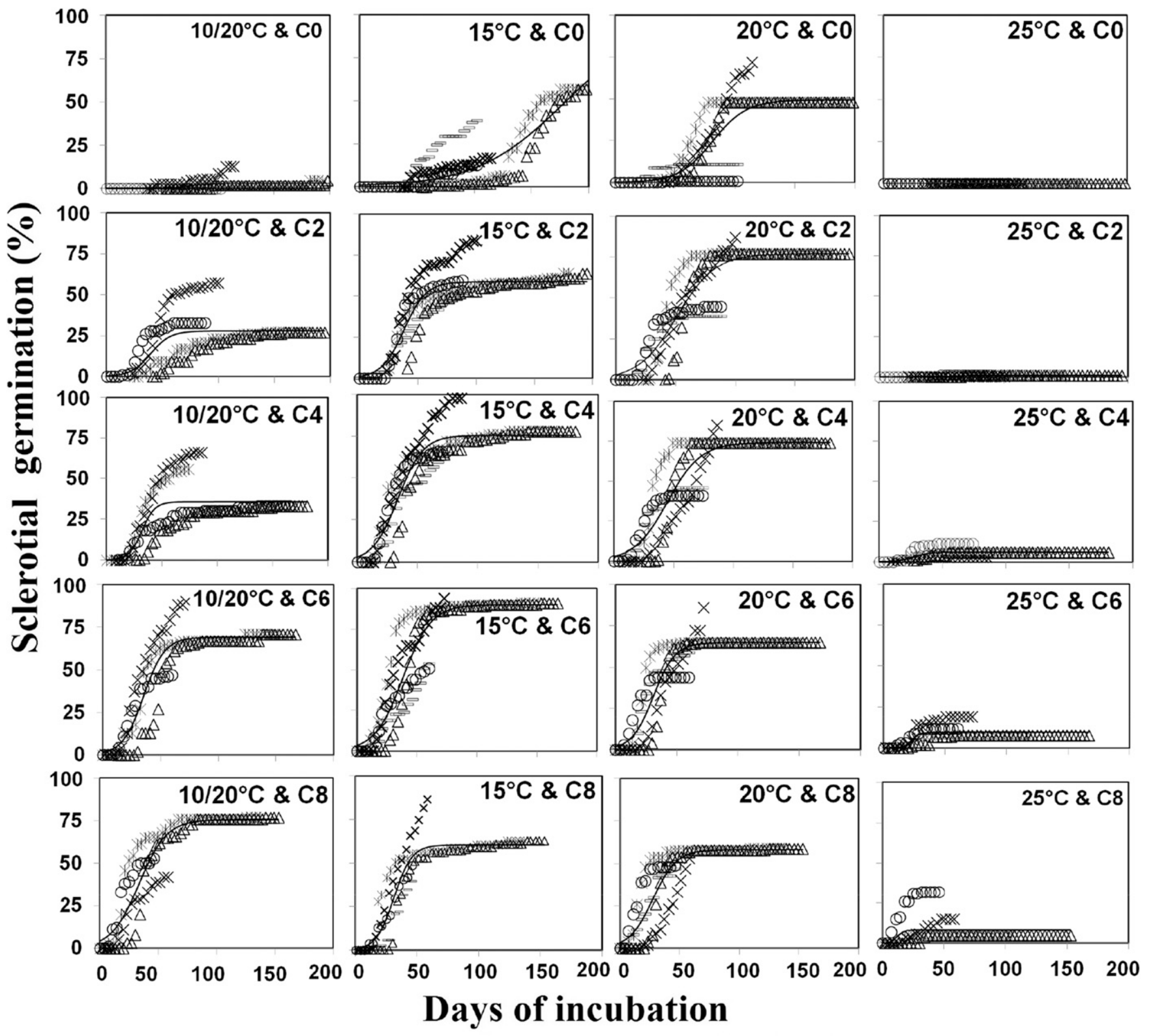

$\times$ Experiment $1 \Delta$ Experiment $2 *$ Experiment 3 ○xperiment 4 - Experiment 5

Fig. 1. Effects of incubation temperatures $\left(10 / 20,15,20\right.$, and $25^{\circ} \mathrm{C}$ [cycle of $12 \mathrm{~h}$ each of darkness and light]) and duration of preconditioning cold treatment $(\mathrm{C} 0=\mathrm{no}$ preconditioning, $\mathrm{C} 2=2$ weeks of preconditioning, $\mathrm{C} 4=4$ weeks of preconditioning, $\mathrm{C} 6=6$ weeks of preconditioning, and $\mathrm{C} 8=8$ weeks of preconditioning) on sclerotial germination of Claviceps purpurea. Various markers represent replication-wise observations on germination percentage and the solid lines represent predicted nonlinear regression lines derived from logistic model $g=a /[1+\exp (-b t+c)]$ at various durations of preconditioning at $4^{\circ} \mathrm{C}$ (in darkness). 
interaction with the length of preconditioning but not the length of preconditioning alone (Table 2). Without the preconditioning cold treatment, the highest asymptote of germination percentage was observed at $15^{\circ} \mathrm{C}$, estimated as $98.4 \%$, followed by $20^{\circ} \mathrm{C}(49.5 \%)$ and $10 / 20^{\circ} \mathrm{C}(3.0 \%)$, while no germination and a $0 \%$ asymptote was estimated at $25^{\circ} \mathrm{C}$ (Fig. 1). For sclerotia subjected to a 2-week preconditioning cold treatment, the highest asymptote of $77 \%$ was estimated at $20^{\circ} \mathrm{C}$ incubation, followed by $15^{\circ} \mathrm{C}(59 \%)$ and $10 / 20^{\circ} \mathrm{C}(28 \%)$, when the very low germination percentage was observed and an asymptote of $0.9 \%$ was estimated at $25^{\circ} \mathrm{C}$ (Fig. 1). As the length of preconditioning cold period increased to 4 weeks, the asymptote of germination percentage was comparable for 15 and $20^{\circ} \mathrm{C}(75.4 \%$ and $74.1 \%$ ), while the maximum germination percentage increased to $5.9 \%$ for $25^{\circ} \mathrm{C}$ and $35.5 \%$ for $10 / 20^{\circ} \mathrm{C}$. As the length of cold treatment period increased further to 6 weeks, the percentage of germinated sclerotia topped at $9.6 \%$ for $25^{\circ} \mathrm{C}, 64.8 \%$ for $20^{\circ} \mathrm{C}, 90.1 \%$ for $15^{\circ} \mathrm{C}$, and $69.0 \%$ for $10 / 20^{\circ} \mathrm{C}$ (Fig. 1). The asymptote was estimated at $60.6,58.1,8.1$, and $75.6 \%$ at $15,20,25$, and $10 / 20^{\circ} \mathrm{C}$, respectively, when the sclerotia were cold treated for 8 weeks (Fig. 1). At the same incubation temperatures, the maximum germination rate increased as the length of preconditioning duration increased from 0 to 8 weeks when sclerotia were incubated at $10 / 20^{\circ} \mathrm{C}$; it peaked, however, at 6 and 4 weeks when incubated at 15 and $20^{\circ} \mathrm{C}$, respectively (Fig. 1). Germination rates of sclerotia at 60 days after incubation (DAI) were also significantly affected by incubation temperatures, duration of preconditioning cold treatment, and their interaction (Table 3). At $60 \mathrm{DAI}$, at any particular temperature, the percent germinated sclerotia increased as cold treatment period extended from 0 to 6 weeks (data not shown). As cold treatment period extended further, the germination percentage decreased for incubation temperatures 15,20 , and $10 / 20^{\circ} \mathrm{C}$ but kept increasing for sclerotia incubated at $25^{\circ} \mathrm{C}$ (data not shown). As the cold treatment period ranged from 2 to 8 weeks, the highest germination percentage was observed at $15^{\circ} \mathrm{C}$ and lowest germination percentage at $25^{\circ} \mathrm{C}$.

Progress rate (parameter $b$ of the logistic model) of sclerotial germination was significantly affected by incubation temperature and the length of preconditioning cold treatment but not their interaction (Table 2). In general, the progress rate of germination increased with increased length of preconditioning cold treatment period (Fig. 1). Because zero or very low germination was observed at $25^{\circ} \mathrm{C}$ without or with a 2-week preconditioning cold treatment, no rate could be estimated for these two combinations. With the data for $\mathrm{C} 0$ of $25^{\circ} \mathrm{C}$ and $\mathrm{C} 2$ of $25^{\circ} \mathrm{C}$ excluded from the analysis, the higher incubation temperature generally resulted in faster progress of sclerotial germination (Fig. 1). The duration of germination from the initiation to stabilization of sclerotial germination count or the period sclerotial germination continued in each treatment was significantly affected by incubation temperature but not by the length of preconditioning cold treatment and their interaction (Table 4). Germination of sclerotia continued for 82 days at $15^{\circ} \mathrm{C}, 80$ days at $10 / 20^{\circ} \mathrm{C}, 44$ days at $20^{\circ} \mathrm{C}$, and only 18 days at $25^{\circ} \mathrm{C}$.
Threshold parameter $c$ of the progress curve, representing time required for onset of germination, was also significantly influenced by the length of preconditioning cold treatment period but the effects of temperature and its interaction with preconditioning treatment were insignificant (Table 2). Regardless of the incubation temperatures, those sclerotia without any preconditioning had the highest $c$ values, or required the longest time for germination to start. Without preconditioning cold treatment, no germination was observed at $25^{\circ} \mathrm{C}$ up to 200 days of incubation; however, some sclerotia germinated within 80 days of incubation at 15,20 , and $10 / 20^{\circ} \mathrm{C}$ (Fig. 2). When sclerotia were cold treated for 2 weeks, the period of days of incubation required for the first germination was also longer at $25^{\circ} \mathrm{C}$ than at the other incubation temperatures tested; however, the difference among different temperatures was minimal when the sclerotia were cold treated for 4 weeks or longer (Fig. 2; Table 5). For all of the incubation temperatures higher than $4^{\circ} \mathrm{C}$ tested in this study, the longer the length of preconditioning cold treatment period, the shorter was the time required for initiation of sclerotial germination, but the improvement resulting from extending the cold treatment beyond 4 weeks was minimal (Fig. 2).

Field studies. Both air and soil temperatures of various locations fluctuated but trended higher from the beginning of the year to the end of the study period (Fig. 3). A regression equation-soil

Table 3. Type III test of fixed effect of incubation temperatures, duration of preconditioning cold treatment, and their interaction on sclerotial germination of Claviceps purpurea at 60 days after incubation

\begin{tabular}{lcccc}
\hline Source $^{\mathbf{a}}$ & Num df & Den df & $\boldsymbol{F}$ value & $\boldsymbol{P}>\boldsymbol{F}$ \\
\hline Temperature & 3 & 66 & 31.81 & $<0.0001$ \\
Precondition & 4 & 66 & 51.80 & $<0.0001$ \\
Temperature $\times$ Precondition & 12 & 66 & 4.39 & $<0.0001$ \\
\hline
\end{tabular}

a Temperature $=$ incubation temperatures: $10 / 20,15,20$, and $25^{\circ} \mathrm{C}$ (cycle of $12 \mathrm{~h}$ each of darkness and light). Precondition $=$ duration of preconditioning treatment: $\mathrm{C} 0=$ no preconditioning and $\mathrm{C} 2, \mathrm{C} 4, \mathrm{C} 6$, and $\mathrm{C} 8=2,4,6$, and 8 weeks, respectively, of preconditioning at $4^{\circ} \mathrm{C}$ (in darkness).

Table 4. Type III test of fixed effect of incubation temperatures, length of preconditioning cold treatment, and their interactions on duration of Claviceps purpurea sclerotial germination

\begin{tabular}{lcccc}
\hline Source $^{\mathbf{a}}$ & Num df & Den df & $\boldsymbol{F}$ value & $\boldsymbol{P}>\boldsymbol{F}$ \\
\hline Temperature & 3 & 61 & 20.91 & $<0.0001$ \\
Precondition & 4 & 61 & 0.28 & 0.8924 \\
Temperature $\times$ precondition & 11 & 61 & 0.58 & 0.878 \\
\hline
\end{tabular}

a Temperature $=$ incubation temperatures: $10 / 20,15,20$, and $25^{\circ} \mathrm{C}$ (cycle of $12 \mathrm{~h}$ each of darkness and light). Precondition $=$ duration of preconditioning treatment: $\mathrm{C} 0=$ no preconditioning and $\mathrm{C} 2, \mathrm{C} 4, \mathrm{C} 6$, and $\mathrm{C} 8=2,4,6$, and 8 weeks, respectively, of preconditioning at $4^{\circ} \mathrm{C}$ (in darkness).

Table 2. Analysis of variance for the effects of incubation temperatures and duration of preconditioning cold treatment on the estimated parameters $a, b$, and $c$ of logistic model $g=a /[1+\exp (-b t+c)]$ fitted to the sclerotial germination progress curve of Claviceps purpurea

\begin{tabular}{|c|c|c|c|c|c|}
\hline Parameter $^{\mathbf{a}}$ & Source $^{\mathbf{b}}$ & Num df & Den df & $F$ value & $P>F$ \\
\hline \multirow[t]{3}{*}{$a$} & Temperature & 3 & 56 & 18.43 & $<0.0001$ \\
\hline & Precondition & 4 & 56 & 1.68 & 0.1675 \\
\hline & Temperature $\times$ precondition & 10 & 56 & 6.96 & $<0.0001$ \\
\hline \multirow[t]{3}{*}{$b$} & Temperature & 3 & 56 & 4.52 & 0.0066 \\
\hline & Precondition & 4 & 56 & 2.85 & 0.0318 \\
\hline & Temperature $\times$ precondition & 10 & 56 & 0.69 & 0.7314 \\
\hline \multirow[t]{3}{*}{$c$} & Temperature & 3 & 56 & 2.39 & 0.0781 \\
\hline & Precondition & 4 & 56 & 3.03 & 0.0249 \\
\hline & Temperature $\times$ precondition & 10 & 56 & 0.56 & 0.8374 \\
\hline
\end{tabular}

\footnotetext{
a Parameter $a$ represents maximum percentage of sclerotia germinated, parameter $b$ represents progress rate of sclerotial germination, and parameter $c$ represents time required for onset of germination.

b Temperature $=$ incubation temperatures: $10 / 20,15,20$, and $25^{\circ} \mathrm{C}$ (cycle of $12 \mathrm{~h}$ each of darkness and light). Condition $=$ duration of preconditioning treatment: $\mathrm{C} 0=$ no preconditioning and $\mathrm{C} 2, \mathrm{C} 4, \mathrm{C} 6$, and $\mathrm{C} 8=2,4,6$, and 8 weeks, respectively, of preconditioning at $4^{\circ} \mathrm{C}$ (in darkness)
} 
temperature $\left({ }^{\circ} \mathrm{C}\right)=(1.0267 \times$ air temperature $)+1.37\left(n=1638 ; R^{2}=\right.$ 0.8751 ) - was fitted to the observed data at the two La Grande sites in 2008, 2009, and 2010 and used to estimate the 2-in. soil temperatures at Aurora and Madras sites from air temperatures.

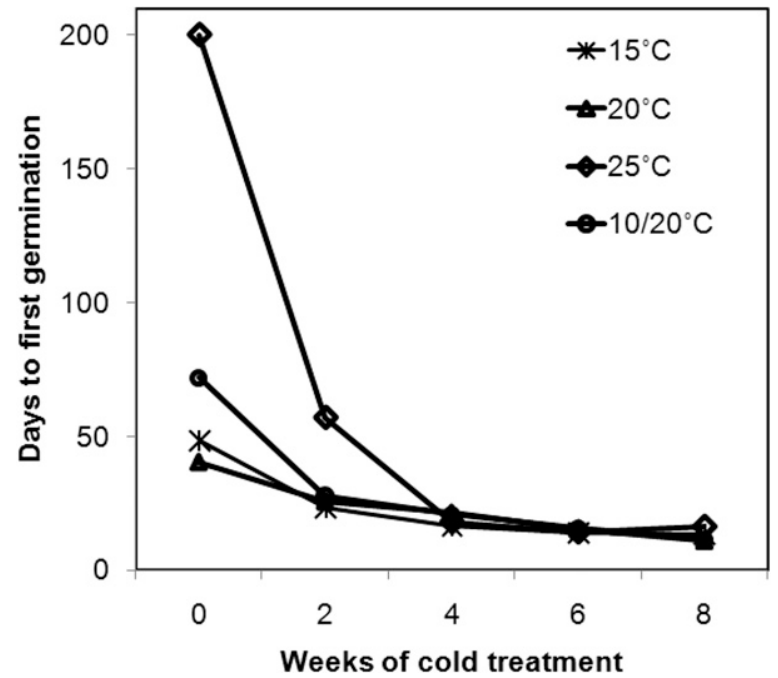

Fig. 2. Effect of incubation temperatures $\left(10 / 20,15,20\right.$, and $25^{\circ} \mathrm{C}$ [cycle of $12 \mathrm{~h}$ each of darkness and light]) and durations of preconditioning at $4^{\circ} \mathrm{C}$ (in darkness) on days required for initiation of Claviceps purpurea sclerotial germination.

Table 5. Type III test of fixed effect of incubation temperatures, length of preconditioning cold treatment, and their interactions on initiation of Claviceps purpurea sclerotial germination, after being preconditioned for four or more weeks at $4^{\circ} \mathrm{C}$

\begin{tabular}{lcccc}
\hline Source $^{\mathbf{a}}$ & Num df & Den df & $\boldsymbol{F}$ value & $\boldsymbol{P}>\boldsymbol{F}$ \\
\hline Temperature & 3 & 38 & 0.12 & 0.947 \\
Precondition & 2 & 38 & 3.63 & 0.036 \\
Temperature $\times$ precondition & 6 & 38 & 0.44 & 0.847 \\
\hline
\end{tabular}

a Temperature $=$ incubation temperatures: $10 / 20,15,20$, and $25^{\circ} \mathrm{C}$ (cycle of $12 \mathrm{~h}$ each of darkness and light). Precondition $=$ duration of preconditioning treatment: $\mathrm{C} 0=$ no preconditioning and $\mathrm{C} 2, \mathrm{C} 4, \mathrm{C} 6$, and $\mathrm{C} 8=2,4,6$, and 8 weeks, respectively, of preconditioning at $4^{\circ} \mathrm{C}$ (in darkness).
The simple model for estimating the onset date of ascospore release performed well in general. The difference between the predicted and observed dates of first ascospore release was within 5 days for 5 experiments, 5 to 15 days for 6 experiments, and greater than 15 days for only 1 of the total 12 experiments. Overall, the prediction model explained 55\% variation of the date of first ascospore release among the 12 experiments (Fig. 4).

\section{Discussion}

The results from the current study demonstrated that preconditioning cold treatment is essential for germination only in areas where the temperature is high (at least higher than $20^{\circ} \mathrm{C}$ ). At lower incubation temperatures $\left(10\right.$ to $\left.20^{\circ} \mathrm{C}\right)$, preconditioning may not be essential but has a role in improving sclerotial germination. Previous results on the requirement of preconditioning on sclerotial germination were mixed. Petch (1937) reported improved germination in C. purpurea ergot from various grasses when exposed to frosty weather. In Derby, England, Mitchell and Cooke (1968) worked with C. purpurea from P.s arundinacea and tested $-5,0,5,10,15$, and $20^{\circ} \mathrm{C}$ of preconditioning temperatures for various periods ( 2 to 20 weeks) before incubation at room temperature $\left(18\right.$ to $\left.21^{\circ} \mathrm{C}\right)$. They observed germination only when sclerotia were preconditioned at 0,5 , or $10^{\circ} \mathrm{C}$. We observed germination of a considerable percentage of sclerotia without cold treatment when they were incubated at constant 15 or $20^{\circ} \mathrm{C}$ or $10 /$ $20^{\circ} \mathrm{C}$. Mitchell and Cooke (1968) tested sclerotial germination at room temperature only for 60 to 80 days after cold treatment, which may not have been sufficient because it took 20 to 95 days for sclerotia to show germination onset in our study. Similarly, in India, Ramakrishnan and Ramakrishnan (1949) preconditioned sclerotia of $C$. purpurea collected from Bambusa sp. at $5^{\circ} \mathrm{C}$ for 10 days before incubation at room temperature. They observed no germination over 2 weeks, which might have resulted from the short preconditioning and incubation (observation) period.

Our laboratory study suggests that the optimal length of cold preconditioning treatment for sclerotial germination was 4 to 6 weeks, which is consistent with the results of Mitchell and Cooke (1968). The cold conditioning requirement should be met in most regions of grass seed production areas in the Pacific Northwest, where the temperature is typically low during winter and early spring. We also found that prolonged cold treatments (longer than 6 weeks) did not further improve ergot germination and might reduce the maximum percentage of germination for sclerotia of $C$. purpurea. However, how prolonged winters affect sclerotial germination in nature remains unknown.

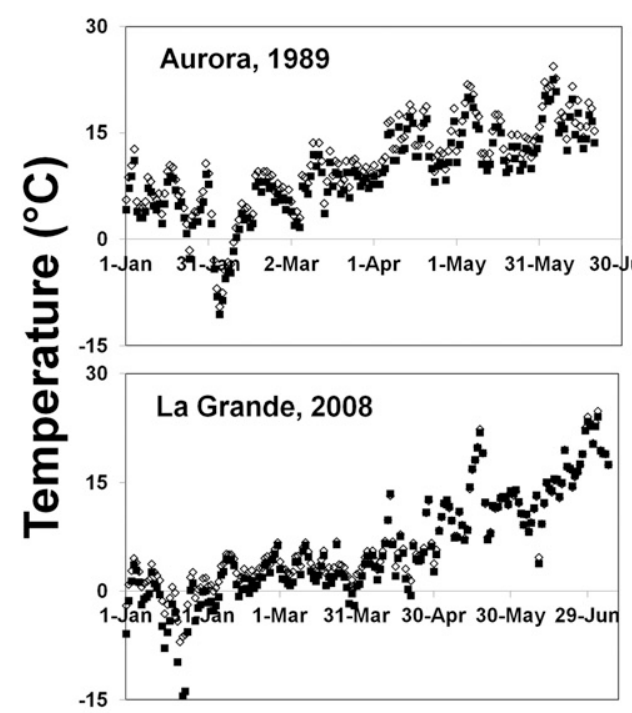

- Air temperature $\left({ }^{\circ} \mathrm{C}\right)$

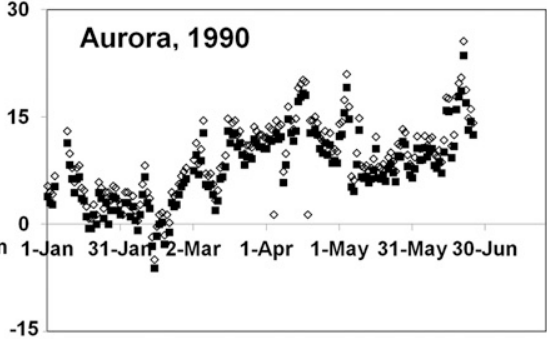

30

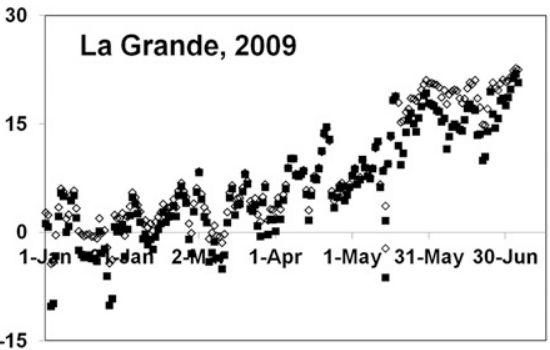

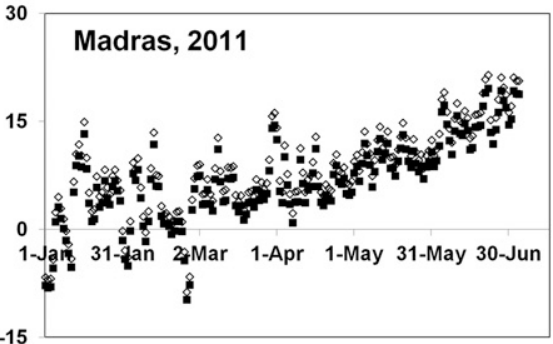

La Grande, 2010

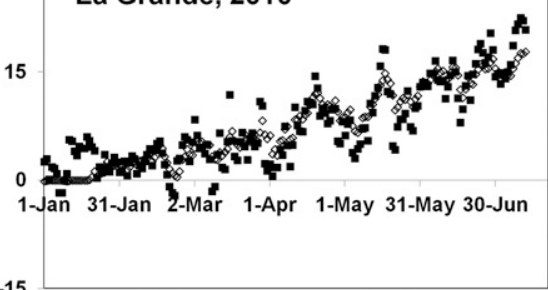

$\diamond$ Soil temperature $\left({ }^{\circ} \mathrm{C}\right)$

Fig. 3. Air and soil temperatures observed at different experiment sites from 1 January to the end of spore trapping period. 
Under laboratory conditions, we observed no germination at continuous $4^{\circ} \mathrm{C}$, the highest germination percentage and quickest germination at $15^{\circ} \mathrm{C}$, and very low germination at $25^{\circ} \mathrm{C}$, consistent with results of Mitchell and Cooke (1968). As far as we are aware, there are no studies concerning cyclic day and night temperatures on sclerotial germination. In our study, the $10 / 20^{\circ} \mathrm{C}$ dark/light cycle had a high percentage of sclerotial germination. Even though $10^{\circ} \mathrm{C}$ or less was reported to be less optimal (Mitchell and Cooke 1968), $20^{\circ} \mathrm{C}$ during the light cycle might have enhanced sclerotial germination. Under controlled temperature conditions, Alderman (1993) studied the release of ascospores from sclerotia of $C$. purpurea bearing mature stromata, and reported an increase in ascospore release with a rise in temperature from 5 to $20^{\circ} \mathrm{C}$. From current results and previous studies (Alderman 1993; Mitchell and Cooke 1968) 10 to $20^{\circ} \mathrm{C}$ appears to be the optimal temperature range for both sclerotial germination and ascospore release.

Understanding the dynamics of sclerotial germination, including duration of germination and subsequent release of ascospores, is important for prediction of ascospore occurrence. Not all sclerotia germinate at the same time. At $10 / 20^{\circ} \mathrm{C}$ and $15^{\circ} \mathrm{C}$, germination was observed through 82 days, compared with 44 days at $20^{\circ} \mathrm{C}$ and 18 days at $25^{\circ} \mathrm{C}$. This indicates a longer window of availability of ascospores at $10 / 20^{\circ} \mathrm{C}$ and at $15^{\circ} \mathrm{C}$ than at higher temperatures $\left(20\right.$ or $\left.25^{\circ} \mathrm{C}\right)$. Wood and Coley-Smith (1982) observed germination of sclerotia of C. purpurea over a period of 5 months. This long window of sclerotial germination and subsequent ascospore release gives the pathogen an added advantage to infect both early- and later-flowering plants.

Diurnal periodicity was observed at all field locations, with more than $75 \%$ ascospores released between 12:00 A.M. and 11:59 A.M. and peak release from 1:00 to 6:00 A.M. Few to no ascospores were trapped between noon and 5:00 P.M. (Alderman 1993). This time (night to early morning) also synchronizes with the time Kentucky bluegrass flowers are open. Claviceps spp. only infect unfertilized flowers, thus making flowers immune to infection once pollinated (Bandyopadhyay et al. 1998; Futrell and Webster 1965). Synchronization of peak release of ascospores with flower opening time results in higher chance of ergot infection.

The current study is the first attempt to develop a model for predicting initiation of ascospore release. We validated the model with historical data of ascospore trapping from various Kentucky bluegrass fields. The performance of the simple model was generally good but, at this stage, it is not accurate enough to be implemented in a commercial production system to guide the timing of fungicide spray. Due to the lack of soil temperature data in the historical data, we developed a simple linear model to estimate the soil temperature from air temperature. This might have increased the prediction error of the model. In the two field experiments at Madras, ascospores were detected on 30 and 31 May, respectively, but trapping of

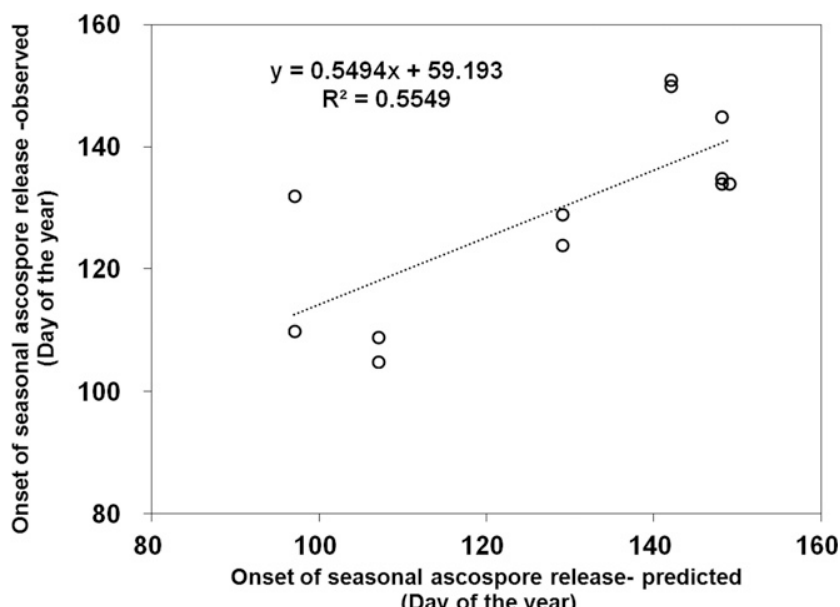

Fig. 4. Relationship between predicted and observed day of the year when seasonal ascospore release started. ascospores was not started until 30 May; therefore, the actual date of first ascospore release might be earlier. Because daily average temperature data are the only temperature data available, we assumed that the effect of fluctuating temperature on preconditioning and on germination of sclerotia was similar to that of the constant temperature (daily mean temperature) but they may have been different. In the model, we assumed that 1 to 3 days of short interruption had no effects but how interrupted temperatures affect the process of preconditioning and germination of sclerotia is still unknown and requires further study. The model only considered the conditions for preconditioning after 1 January, and ignored the fact that some sclerotia might have already passed the process during autumn before the temperature reduced below $0^{\circ} \mathrm{C}$. This might have also contributed to the errors in prediction of first release of ascospores of $C$. purpurea in the field studies.

The results of this study will advance our understanding of the role of environmental conditions (specifically temperature) in ergot germination and ascospore release and provide information required for forecasting and management of ergot in Kentucky bluegrass.

\section{Acknowledgments}

This study was funded by the Agricultural Research Foundation, Oregon State University.

\section{Literature Cited}

Alderman, S. C. 1991. Spatial pattern of Claviceps purpurea and Gloeotinia temulenta in the Willamette Valley of Oregon. Plant Dis. 75:1172-1175.

Alderman, S. C. 1993. Aerobiology of Claviceps purpurea in Kentucky bluegrass. Plant Dis. 77:1045-1049.

Alderman, S. C. 2006. Ergot: Biology and Control. Online publication. http:// www.ars.usda.gov/SP2UserFiles/person/81/ErgotDVDtranscript.pdf

Alderman, S. C., and Barker, R. E. 2003. Evaluation of resistance to ergot, caused by Claviceps purpurea, in Kentucky bluegrass, based on incidence and severity estimates. Plant Dis. 87:1043-1047.

Alderman, S. C., Coats, D. D., and Crowe, F. J. 1996. Impact of ergot on Kentucky bluegrass grown for seed in northeastern Oregon. Plant Dis. 80: 853-855.

Alderman, S. C., Coats, D. D., Crowe, F. J., and Butler, M. D. 1998. Occurrence and distribution of ergot and estimates of seed loss in Kentucky bluegrass grown for seed in central Oregon. Plant Dis. 82:89-93.

Alderman, S. C., Halse, R. R., and White, J. F. 2004. A reevaluation of the host range and geographical distribution of Claviceps species in the United States. Plant Dis. 88:63-81.

Alderman, S. C., Walenta, D. L., and Hamm, P. B. 2010. Timing of occurrence of Claviceps purpurea ascospores in northeast Oregon. Online publication. Plant Health Prog. doi:10.1094/PHP-2010-1123-01-RS

Bandyopadhyay, R., Frederickson, D. E., McLaren, N. W., Odvody, G. N., and Ryley, M. J. 1998. Ergot: A new disease threat to sorghum in the Americas and Australia. Plant Dis. 82:356-367.

Bove, F. J. 1970. The Story of Ergot. S. Karger, Basel, New York.

Bretag, T. W., and Merriman, P. R. 1981. Effect of burial on survival of sclerotia and production of stromata by Claviceps purpurea. Trans. Br. Mycol. Soc. 77:658-660.

Butler, M. D., Alderman, S. C., Hammond, P. C., and Berry, R. E. 2001 Association of insects and ergot (Claviceps purpurea) in Kentucky bluegrass seed production fields. J. Econ. Entomol. 94:1471-1476.

Butler, M. D., Hart, J. M., and Young, W. C., III. 2002. Kentucky bluegrass seed production in Central Oregon. Online publication. Oregon State University Extension Service. http://ir.library.oregonstate.edu/xmlui/handle/1957/20227

Cagas, B., and Machac, R. 2002. Different pathogenicity of ergot isolates (Claviceps purpurea [Fr.] Tul.) on Kentucky bluegrass (Poa pratensis L.) Plant Prot. Sci. 38:18-22.

Campbell, W. P., and Tyner, L. E. 1959. Comparison of degree and duration of susceptibility of barley to ergot and true loose smut. Phytopathology 49:348-349.

Chastain, T. G. 1992. Relationship of ergot to Kentucky bluegrass seed production and quality. J. Appl. Seed Prod. 10:7-10.

Cunfer, B., Mathre, D. E., and Hockett, E. A. 1975. Factors influencing the susceptibility of male-sterile barley to ergot. Crop Sci. 15:194-196.

Darlington, L. C., and Mathre, D. E. 1976. Resistance of male sterile wheat to ergot as related to pollination and host genotype. Crop Sci. 16:728-730.

Futrell, M. C., and Webster, O. J. 1965. Ergot infection and sterility in grain sorghum. Plant Dis. Rep. 49:680-683.

Gupta, G. K., Subbarao, G. V., and Saxena, M. B. L. 1983. Relationship between meteorological factors and the occurrence of ergot disease (Claviceps microcephala) of pearl millet. Trop. Pest Manage. 29:321-324.

Hamm, P. B., David, N. L., and Horneck, D. A. 2007. Controlling ergot with soil and foliar applied fungicides in seedling tall fescue var. Labyrinth grown for seed in the southern Columbia Basin. Pages 84-85 in: Seed Production 
Research Ext/CrS 126. Oregon State University and USDA-ARS. Online: http://cropandsoil.oregonstate.edu/system/files/u1473/complete.pdf

Hamm, P. B., David, N. L., and Horneck, D. A. 2008. Controlling ergot with foliar applied fungicides in seedling perennial ryegrass var. Americus grown for seed in the southern Columbia Basin. Pages 52-53 in: Seed Production Research Ext/ CrS 127. Oregon State University and USDA-ARS. Online: http://cropandsoil. oregonstate.edu/system/files/u1473/2007SeedProductionResearch.pdf

Johnston, W. J., Golob, C. T., Sitton, J. W., and Schultz, T. R. 1996. Effects of temperature and postharvest field burning of Kentucky bluegrass on germination of sclerotia of Claviceps purpurea. Plant Dis. 80:766-768.

Luttrell, E. S. 1980. Host-parasite relationship and development of the ergot sclerotium in Claviceps purpurea. Can. J. Bot. 58:942-958.

McCrea, A. 1931. The reactions of Claviceps purpurea to variations of environment. Am. J. Bot. 18:50-78.

Mitchell, D. T., and Cooke, R. C. 1968. Some effects of temperature on germination and longevity of sclerotia in Claviceps purpurea. Trans. Br. Mycol. Soc. 51:721-729.

Montes-García, N., Prom, L. K., Williams-Alanis, H., and Isakeit, T. 2009. Effect of temperature and relative humidity on sorghum ergot development in northern Mexico. Australas. Plant Pathol. 38:632-637.

Mower, R. L., and Hancock, J. G. 1975a. Sugar composition of ergot honeydews. Can. J. Bot. 53:2813-2825.

Mower, R. L., and Hancock, J. G. 1975b. Mechanism of honeydew formation by Claviceps species. Can. J. Bot. 53:2826-2834.

Oregon State University. 2013. Oregon Grass Seed Crop Estimates. Online publication. Oregon State University Extension economics office. http://cropandsoil.oregonstate. edu/system/files/u1473/CDS11-13G.pdf

Petch, T. 1937. More about Claviceps. The Naturalist 961:25-28.

Ramakrishnan, T. S., and Ramakrishnan, K. 1949. Ergot on Bamboo. Curr. Sci. 18: 343-344.

Schultz, T. R., Johnston, W. J., Golob, C. T., and Maguire, J. D. 1993. Control of ergot in Kentucky bluegrass seed production using fungicides. Plant Dis. 77:685-687.
Shaw, S. 1986. Evaluation of Baytan for control of ergot contaminants in cereal seed. Pflanzenschutz Nachr. 39:47-70.

Uppala, S., Wu, B. M., and Alderman, S. C. 2012. Effects of preconditioning cold treatments and incubation temperature on germination of ergot bodies of Claviceps purpurea from Kentucky bluegrass. Phytopathology 102:S4.123. http://www.apsnet.org/meetings/meetingarchives/2012annual/program/Documents/ AnnualMeetingSupplement.pdf

Uppala, S., Wu, B. M., Alderman, S. C., and Gilmore, L. 2011. Studies on epidemiology of ergot in Kentucky bluegrass. Central Oregon Agricultural Research Center 2011 Annual Report. Online publication. Oregon State University Extension system. http:// oregonstate.edu/dept/coarc/sites/default/files/publication/11_ergot_bluegrass_0.pdf

USDA-NASS. 2013. Value of Washington's 2012 agricultural production. Online publication. United States Department of Agriculture National Agricultural Statistics Service. http://www.nass.usda.gov/Statistics_by_State/Washington/ Publications/Current_News_Release/vop10_1.pdf

Walenta, D. L., Hamm, P. B., and Alderman, S. C. 2009. Monitoring of ergot (Claviceps purpurea) ascospore release to better time fungicide application in NE Oregon grass seed. Pages 34-38 in: 2008 Seed Production Research Report Ext/CrS 128. Online publication. http://cropandsoil.oregonstate.edu/ system/files/u1473/2008_Seed_Production_Research.pdf

Wood, G., and Coley-Smith, J. R. 1980. The effectiveness of fungicides used against Claviceps purpurea attacking male-sterile barley in field trials. Ann. Appl. Biol. 96:169-175.

Wood, G., and Coley-Smith, J. R. 1982. Epidemiology of ergot disease (Claviceps purpurea) in open-flowering male-sterile cereals. Ann. Appl. Biol 100:73-82

Wu, B. M., Hamm, P. B., Affeldt, R., Butler, M. D., and Simmons, R. 2010 Effects of weather conditions on ergot in Kentucky bluegrass in central Oregon. Pages 5-10 in: Central Oregon Agricultural Research Center 2009 Annual Report. Online publication. http://oregonstate.edu/dept/coarc/2009annual-report 